\title{
The Management of Axillary Lymph Nodes in Breast Cancer - A Retrospective Single-Centre Study
}

\author{
Elena Mihaela Vrabie ${ }^{1}$, Mihnea Alecu ${ }^{1,2}$, Ciprian Cirimbei ${ }^{1,2}$, Claudiu Daha ${ }^{1,2}$, Virgiliu Mihail Prunoiu ${ }^{1,2}$, \\ Dana Lucia Stanculeanu ${ }^{1,2}$, Daniela Zob ${ }^{1,2}$, Alexandra Baciu' ${ }^{1}$, Ina Petrescu ${ }^{3}$, Laurentiu Simion ${ }^{1,2}$ \\ "Carol Davila" University of Medicine and Pharmacy, Bucharest, Romania \\ 2Department of Surgery, "Prof. Dr. Al. Trestioreanu" Oncology Institute Bucharest, Romania \\ ${ }^{3}$ Department of Plastic and Reconstructive Surgery, Emergency University Hospital, Bucharest, Romania
}

${ }^{*}$ Corresponding author: Mihnea Alecu, MD, PhD Department of Surgery "Prof. Dr. Al. Trestioreanu" Oncology Institute Bucharest, Romania

Soseaua Fundeni, no. 252

E-mail: mihneaalecu@yahoo.com

\section{Rezumat}

Management-ul ganglionilor limfatici axilari în cancerul mamar - studiu retrospectiv, unicentric

Introducere: Prezentăm experiența centrului nostru în tratamentul chirurgical al cancerului mamar, comparând utilizarea disecției ganglionare axilare cu biopsia ganglionului limfatic santinelă (SNLB). Metode: Am realizat o analiză retrospectivă a cazurilor de cancer mamar din Clinica de Chirurgie Oncologica 1, Institutul Oncologic „Alexandru Trestioreanu”, Bucureşti, în perioada decembrie 2019 - decembrie 2020. Expunem situațiile în care disecția ganglionară axilară poate fi înlocuită cu SNLB şi limitările acestei metode.

Rezultate: Deşi utilizarea SNLB prezintă avantaje comparativ cu disecția ganglionară axilară, aceasta este limitată de detecția în stadii precoce a cancerului mamar şi de necesitatea completării tratamentului chirurgical cu disecția axilară în cazul SNLB cu rezultat pozitiv.

Concluzii: Înlocuirea disecției ganglionare axilare cu SNLB reprezintă un deziderat al următoarelor decade pentru tratamentul optim al cancerului mamar în stadii precoce, cu scaderea complicațiilor postoperatorii şi îmbunătățirea calității vieții.

Cuvinte cheie: cancer mamar, ganglion santinelă, limfodisecție axilară

\section{Abstract}

Introduction: We are presenting the experience of our centre with 
the surgical treatment of breast cancer, by comparing the use of axillary node dissection with sentinel lymph node biopsy (SNLB).

Methods: We have made a retrospective analysis of breast cancer cases in the Surgical Oncology Clinic no. 1, "Alexandru Trestioreanu" Oncology Institute, Bucharest, in the period between December 2019 and December 2020. We are presenting the situations in which axillary node dissection can be replaced with SNLB and the limitations of this method.

Results: Although the use of SNLB has advantages compared to axillary node dissection, it is limited by the early detection of breast cancer and by the necessity of adding axillary dissection to surgical treatment in the case of positive SNLB.

Conclusions: The replacement of axillary node dissection with SNLB is a desideratum for the following decades in view of an optimal treatment of early-stage breast cancer, with fewer postoperative complications and a better life quality.

Key words: breast cancer, sentinel node, axillary lymph dissection

\section{Introduction}

Axillary node dissection represents an important component of breast cancer therapy. It allows for the evaluation of the status of locoregional lymph nodes, which is one of the most important prognostic factors. Based on it, the indication of adjuvant oncological treatment can be established more precisely $(1,2)$. Despite its substantial role, axillary node dissection is associated with numerous complications, which can limit the patient's functionality and can significantly reduce the quality of his / her life. The most frequent complications include lymphoedema, lymphangitis, nerve injuries, shoulder joint dysfunctions and upper limb pareses $(3,4)$. The less invasive method for the evaluation of the status of axillary lymph nodes in the context of breast cancer is represented by sentinel lymph node biopsy (SNLB). This is the first affected by tumour metastases and its negative status renders tumour spread to downstream nodes less likely (4). The location of SNLB can be established by using vital dyes or radioactive tracers. They are injected peritumorally and are taken up to the lymph nodes by tumour draining. SNLB is also useful for the staging of lymph nodes located in other areas (interpectoral, internal mammary, supraclavicular, intramammary), where invasion in the context of breast cancer is possible, but which are less frequent. Moreover, SNLB has also proven to be useful in the staging of axillary lymph nodes associated with infraclinical breast lesions, their role being that of guiding the extension of the resection. Currently, SNLB is first-line in the management of axillary lymph nodes in clinically node negative patients and are not associated with significant risk factors. Axillary node dissection applies to cases in which more than 2 axillary lymph nodes are invaded by the tumour (5). There is the possibility of replacing axillary node dissection with SNLB, considering its fewer complications compared to axillary node dissection.

The aim of our study is to compare the use of the sentinel lymph node technique with axillary node dissection. The study is a retrospective single-centred one (the Surgical Oncology Clinic no. 1, "Alexandru Trestioreanu" Oncology Institute, Bucharest).

\section{Material and Method}

Our study consists of a retrospective analysis of breast cancer cases in the Surgical Oncology Clinic no. 1, "Alexandru Trestioreanu" Oncology Institute, Bucharest, in the period between December 2019 - December 2020. It includes an initial number of 464 patients. The diagnosis for patients included in the study is histopathological breast cancer, 
irrespective of its location; HER-2 status (positive or negative); the patients underwent surgical treatment and were evaluated for axillary node invasion. The following patients were excluded from the study: patients with unresectable breast cancer, patients who did not present for periodic re evaluations, patients who rejected surgical intervention and patients for whom, according to medical documents, neither axillary node dissection nor SNLB was performed. Subsequently, a group of 218 patients remained. Patient data was retrieved from observation sheets and from the surgery protocol and were analysed in accordance with ethical and data confidentiality principles.

The analysed parameters were the following:

- patient distribution, according to age and gender;

- the type of surgical techniques used, the type of axillary lymph node staging method, the histopathological type, the $\mathrm{T}$ stage (from breast cancer TNM staging);

- the link between the histopathological type and the tumour differentiation degree;

- the radical excision of axillary lymph nodes following sentinel lymph node biopsy.

The probability of diagnosis was established based on clinical examination, laboratory tests, radiological and imaging investigations (mammography, computed tomography, magnetic resonance imaging). The diagnosis was confirmed through the histopathological examination of the resection piece or of the thick-needle aspiration material. The surgical treatment consisted of Madden modified radical mastectomy or breast conserving surgery. The staging and management of axillary lymph nodes were carried out by using the sentinel lymph node technique or axillary node dissection. Patient postoperative follow-up was planned according to the protocol: yearly clinical examination 3 years after surgery, yearly mammography 3 years after diagnosis.

\section{Results}

The highest cancer incidence was seen in the 60-69 age category (Fig. 1) and in females $(99.56 \%)$. The surgical techniques used in the treatment of patients included in the analysed group consisted of Madden modified radical mastectomies and breast conserving surgery. Most patients underwent a Madden modified radical mastectomy, namely $76 \%$ of the total surgical procedures carried out in the group (Fig. 2).

The axillary lymph node staging methods included the radical excision of axillary lymph nodes and SNLB. We found that most of the procedures were represented by the radical excision of axillary lymph nodes (88.53\% of all procedures) compared to the much lower share represented by SNLB (11.46\% of all procedures), as illustrated in Fig. 3.

Based on the analysis of a series of parameters of patients who underwent

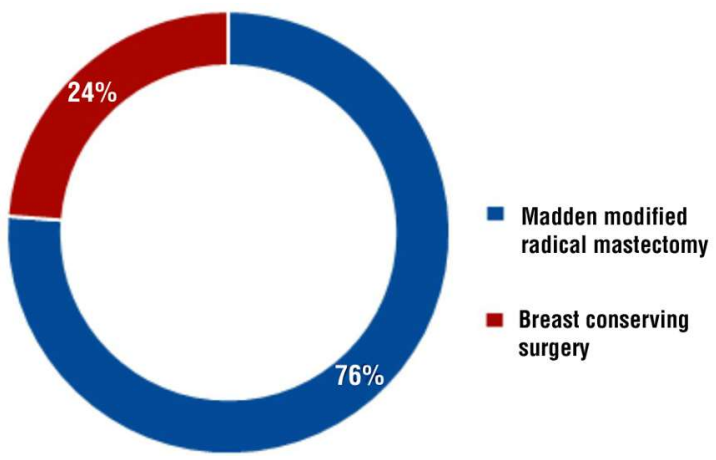

Figure 2. Surgical techniques used in the treatment of breast cancer

Figure 1. Patient distribution, according to age 


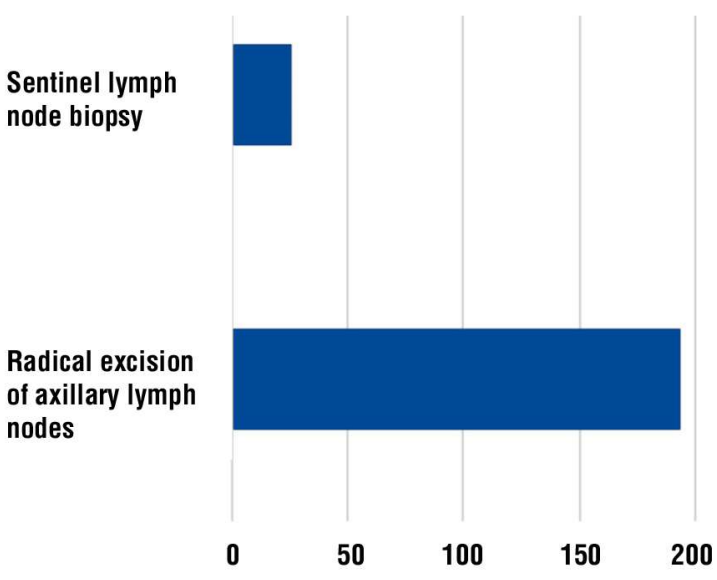

Figure 3. Axillary lymph node staging methods

sentinel lymph node biopsy, we drew out a set of characteristics. Most often, SNLB was carried out in the 60-69 age category, which was followed by the 40-49 and 50-59 age categories (Fig. D). The most frequent histopathological type of tumour in the group of patients who underwent SNLB was represented by invasive ductal carcinoma ( $88 \%)$, the other histopathological types being less represented (Fig. 5). However, this element is not entirely relevant, as invasive ductal carcinoma is, in any case, the most frequent one. $72 \%$ of the patients included in this group

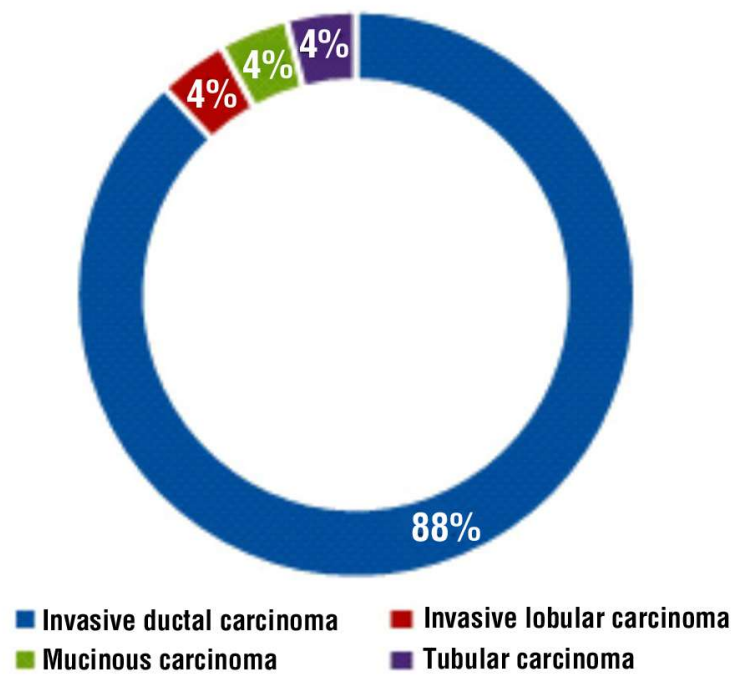

Figure 5. The histopathological type of tumours in the sentinel lymph node biopsy group

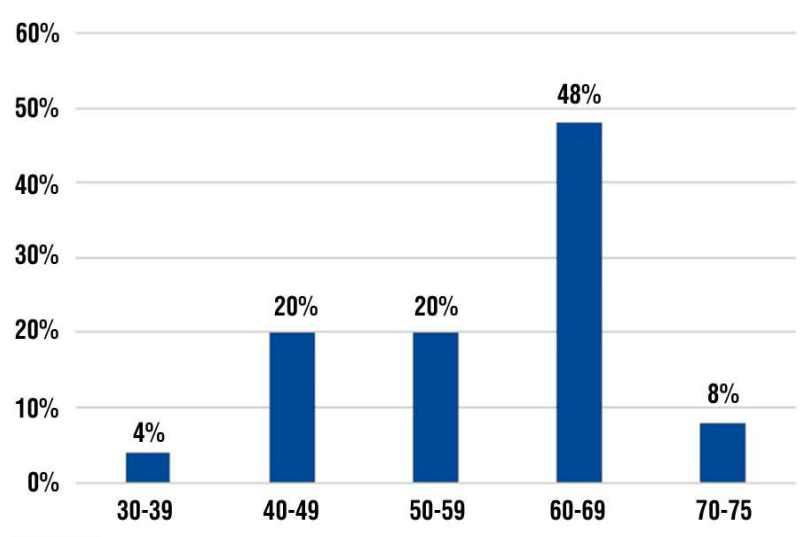

Figure 4. Case distribution, according to age, in the sentinel lymph node biopsy group

underwent Madden modified radical mastectomy (Fig. 6). The analysis of case distribution according to the $\mathrm{T}$ stage (from breast cancer TNM staging) lead to the conclusion that the highest percentage of tumours for which SNLB was carried out belonged to the $\mathrm{T} 1$ stage (Fig. $\lambda$ ).

In the SNLB group, the positive SNLB cases were also analysed and, in addition to the therapy, the radical excision of axillary lymph nodes was also carried out. Thus, the histopathological type most frequently associated with a positive SNLB was also represented by invasive ductal carcinoma, namely 71\% (Fig. 8). Poorly differentiated tumours (G3) were also more frequently associated

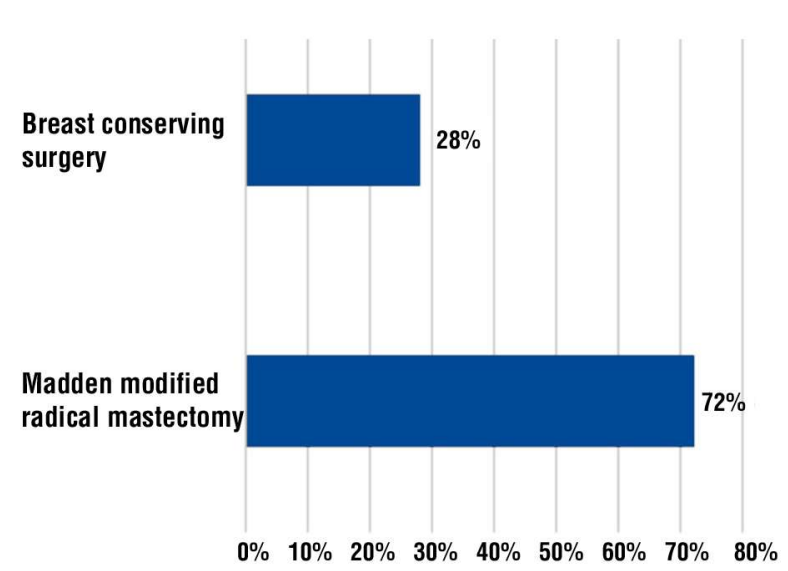

Figure 6. Surgical procedures carried out in the sentinel lymph node biopsy group 


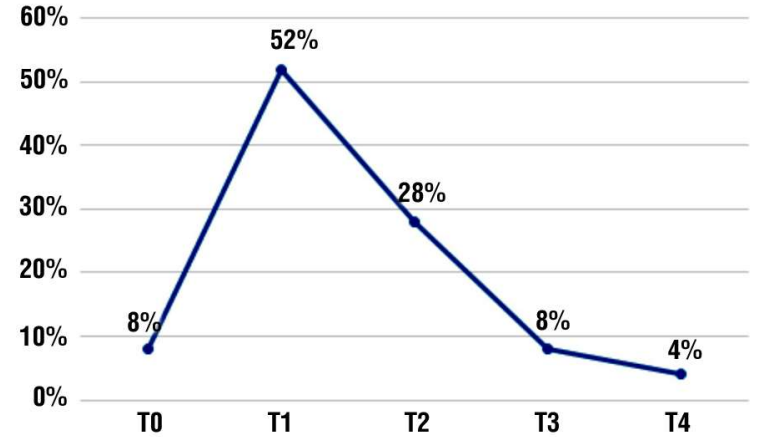

Figure 7. Case distribution, according to the T stage, in the sentinel lymph node biopsy group

with a positive SNLB and required the radical excision of axillary nodes (Fig. 9). The positive result of SNLB was directly proportional to tumour progression from T1 to T4 (Fig. 1O). In $32 \%$ of the cases, the result of SNLB was negative, in which case no radical excisions were carried out.

\section{Discussions}

The prevalence of axillary node metastases is directly proportional to the size of the primary tumour and it grows as the stage of the condition becomes more advanced (6). The management of axillary lymph nodes in early breast cancer has been a challenge over the past decades, with less use of axillary node dissection and an attempt to increasingly use

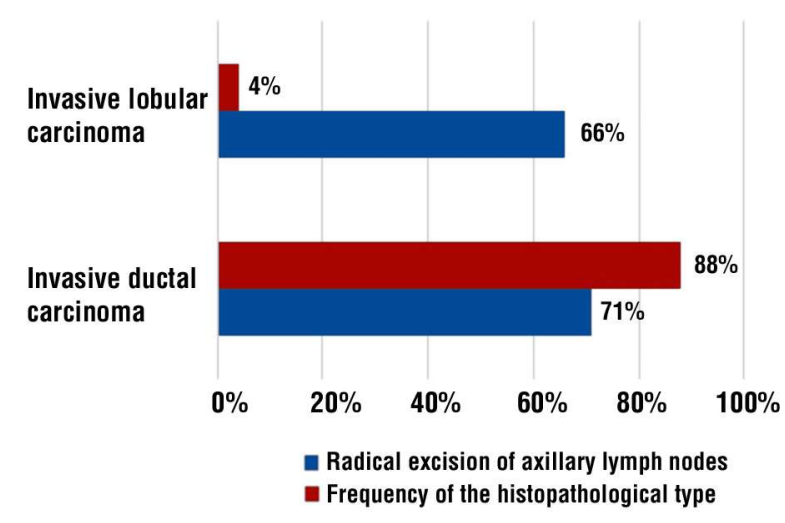

Figure 8. Radical excision of axillary lymph nodes following sentinel lymph node biopsy - the association with the histopathological type of tumours

SNLB (7). The technique is associated with a sensitivity of $68 \%$, a specificity of $98 \%$, a positive predictive value of $67 \%$, a negative predictive value of $98 \%$ and has proven to be a safe and effective alternative to axillary node dissection in $\mathrm{T} 1, \mathrm{~T} 2$ and clinically nodenegative breast cancer $(8,9)$. Comparative studies on early and late locoregional recurrence respectively in patients with $\mathrm{T} 1, \mathrm{~T} 2$, clinically node-negative breast cancer, but with metastases in 1-2 sentinel lymph nodes, have shown insignificant differences between the use of axillary node dissection and that of SNLB (10-12).

However, axillary node dissection remains the most used technique, irrespective of the tumour stage, as its replacement with SNLB requires experience in carrying out this

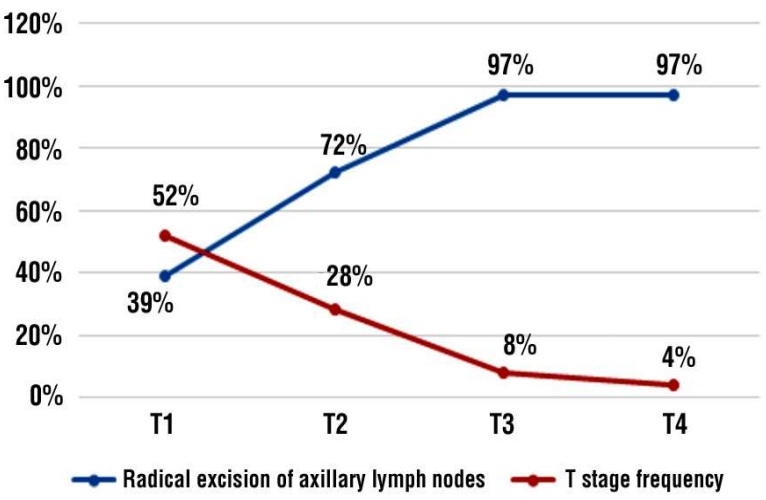

Figure 10. Radical excision of axillary lymph nodes following sentinel lymph node biopsy - the association with the T stage 
technique and access to proper equipment.

Future directions consist of the introduction of first-line SNLB in early breast cancer patients, dissection applying to cases with more than 2 positive sentinel lymph nodes or with clinically palpable lymph nodes respectively (11). The contraindications of SNLB include: neoadjuvant locoregional or systemic treatments, history of breast or axillary surgery, breast tumours larger than $4 \mathrm{~cm}$ or with skin or chest wall invasion, mastitis, suspicious axillary adenopathies, pregnancy, lactation.

One of the most frequent complications of axillary node dissection is the formation of postoperative seromas. The attempts to reduce the rate of complications and to improve the axillary node dissection surgical technique have led to the introduction of the ultrasonic scalpel - the harmonic scalpel $(13,14)$. Part of the comparative studies on node dissection carried out with a harmonic scalpel as compared to a classic electrocautery have shown similar operative times, with no significant differences in terms of axillary drainage volume and with the same interval of time for limb mobility recovery $(15-17)$. There are however studies showing a reduction of operative times and of axillary drainage following axillary dissection when using a harmonic scalpel. Therefore, the use of the harmonic scalpel requires further studies on the cost-benefit relationship, considering the high cost of this technique compared to the traditional method $(18,19)$.

Better results in terms of seroma prevention have been obtained by using the Thunderbeat device. It can be used for tissue dissection and haemostasis on vessels of up to $7 \mathrm{~mm}$, obtaining an efficient haemostasis, while tissue dissection is fast and allows for shorter operative times. In addition, Thunderbeat ensures a more versatile tissue handling compared to other instruments used for haemostasis.

\section{Conclusions}

Axillary node dissection is part of breast cancer therapy. Replacing it with SNLB in early stages is a laborious process, which has however evolved over the past years. The complications associated with axillary lymph node dissection can be reduced by using new intraoperative dissection devices, the harmonic scalpel and Thunderbeat, which become an important object for study, considering the optimistic results obtained.

\section{Conflicts of Interest}

The authors declared no potential conflicts of interest with respect to the research, authorship, and/or publication of this article.

\section{Ethics Approval}

The study was conducted respecting the actual ethical principles, with the consent of the health units involved. Informed consent of all patients was obtained and all legal measures were taken to protect personal data. Patients' consent to use the photographs was also obtained.

\section{References}

1. Janni W, Kühn T, Schwentner L, Kreienberg R, Fehm T, Wöckel A. Sentinel node biopsy and axillary dissection in breast cancer: the evidence and its limits. Dtsch Arztebl Int. 2014;111(14):244-9.

2. Chao C, McMasters KM. Sentinel lymph node biopsy in breast cancer. Methods Mol Med. 2006:120:91-111.

3. Manca G, Rubello D, Tardelli E, Giammarile F, Mazzarri S, Boni G, et al. Colletti. Sentinel Lymph Node Biopsy in Breast Cancer: Indications, Contraindications, and Controversies. Clin Nucl Med. 2016;41(2):126-33.

4. Abass MO, Gismalla MDA, Alsheikh AA, Elhassan MMA. Axillary Lymph Node Dissection for Breast Cancer: Efficacy and Complication in Developing Countries. J Glob Oncol. 2018:4:1-8.

5. Yan M, Abdi M, Falkson C. Axillary Management in Breast Cancer Patients: A Comprehensive Review of the Key Trials. Clin Breast Cancer. 2018;18(6): e1251-e1259.

6. Mustafa IA, Bland KI. Indications for axillary dissection in T1 breast cancer. Ann Surg Oncol. 1998;5(1):4-8.

7. Garcia-Etienne CA, Mansel RE, Tomatis M, Heil J, Biganzoli L, Ferrari A, et al. Trends in axillary lymph node dissection for early-stage breast cancer in Europe: Impact of evidence on practice. Breast. 2019;45:89-96.

8. Pusina S. Diagnostic accuracy of sentinel lymph node biopsy in axillary lymph nodes at the early stages of breast cancer. Med Arch. 2013;67(4): 252-5.

9. Nayyar A, Strassle PD, Shen MR, Black JA, Gallagher KK, McGuire KP. Survival analysis of early-stage breast cancer patients undergoing axillary lymph node dissection and sentinel lymph node dissection. Am J Surg. 2018;216(4):706-712

10. Yen TWF, Laud PW, Pezzin LE, McGinley EL, Wozniak E, Sparapani R, et al. Prevalence and Consequences of Axillary Lymph Node Dissection in the Era of Sentinel Lymph Node Biopsy for Breast Cancer. Med Care. 2018; $56(1): 78-84$. 
11. Veronesi P, Corso G. Standard and controversies in sentinel node in breast cancer patients. Breast. 2019;48 Suppl 1:S53-S56

12. Dumitru D, Khan A, Catanuto G, Rocco N, Nava MB, Benson JR. Axillary surgery in breast cancer: the beginning of the end. Minerva Chir. 2018; 73(3):314-321.

13. Park TS, Thomas SM, Rosenberger LH, Fayanju OM, Plichta JK, Blitzblau $\mathrm{RC}$, et al. The Association of Extent of Axillary Surgery and Survival in Women with N2-3 Invasive Breast Cancer. Ann Surg Oncol. 2018; 25(10):3019-3029.

14. Militello G, De Marco P, Falco N, Kabhuli K, Mascolino A, Licari L, et al. Is it really useful the Harmonic scalpel in axillary dissection for locally advanced breast cancer? A case series. G Chir. 2016; 37(6):262-265.

15. Manjunath S, Ramesh RS, Shivakumar K, Goel V. Ultrasonic shears versus electrocautery in axillary dissection for breast cancer-a randomized controlled trial. Indian J Surg Oncol. 2014;5(2):95-8

16. Hung SH, Chu D, Chen FM, Chen T, Chen RC. Evaluation of the harmonic scalpel in breast conserving and axillary staging surgery. J Chin Med Assoc. 2012;75(10):519-23.

17. Nawaz A, Waqar S, Khan A, Mansoor R, Butt UI, Ayyaz M. Harmonic Scalpel versus Electrocautery in Axillary Dissection in Carcinoma Breast. J Coll Physicians Surg Pak. 2015;25(12):870-3.

18. Obonna GC, Mishra RK. Differences between Thunderbeat, LigaSure and Harmonic Scalpel Energy System in Minimally Invasive Surgery. World J Lap Surg 2014;7(1):41-44.

19. Gambardella C, Clarizia G, Patrone R, Offi C, Mauriello C, Romano R, et al. Advanced hemostasis in axillary lymph node dissection for locally advanced breast cancer: new technology devices compared in the prevention of seroma formation. BMC Surg. 2019; 18(Suppl 1):125. 